\title{
Biological Purification Process of CF-Containing Waste Waters from Petroleum
}

\author{
${ }^{1}$ Elvira I. Mukhitova, ${ }^{2}$ Alena A. Inyusheva, ${ }^{3}$ Nina N. Smirnova \\ ${ }^{1,3}$ Kazan Federal University \\ ${ }^{2}$ «Teplosnab» LLC \\ Email: elvirusik.89@mail.ru
}

Received: 20 ${ }^{\text {th }}$ August 2019, Accepted: $30^{\text {th }}$ September 2019, Published: $31^{\text {st }}$ October 2019

\begin{abstract}
In the article, the use of the drug, Etafos-f at concentrations of $10^{-4}, 10^{-5}, 10^{-6}, 10^{-7} \mathrm{~g} / \mathrm{dm}^{3}$. as an activator of activity of the biocenosis of activated sludge in the purification of coolant-containing wastewater. The study found that the addition of the drug in a concentration of $10^{-4} \mathrm{~g} / \mathrm{dm}^{3}$ reduces the content of petroleum products in the wastewater 7 times compared with the initial sample $\left(144.6 \mathrm{mg} / \mathrm{dm}^{3}\right)$ and 3 times compared with the classical biological treatment.
\end{abstract}

Keywords

Biological Purification, Water-Soluble Cutting Fluids (CF), Biologically Active Substances (BAS)

\section{Introduction}

The use of water-soluble cutting fluids (CF) is an integral part of the technological process of metal machining. Modern technological emulsions are toxic to representatives of the biocenosis of aquatic ecosystems in the concentration range of 3.0-0.015\% [1]. In the process of metalworking fluids are microoperation and lose the complex technological and hygienic properties [2], resulting in frequent replacement of the $\mathrm{CF}$ and increase CF-containing wastewater.

Wastewater engineering enterprises are multi-component and multiphase water systems. The composition of such effluents includes mineral oils, surfactants, bactericidal and anticorrosive additives, in many cases, heavy metals, as well as toxic products of destruction of $\mathrm{CF}$ components.

During salvo discharges of CF-containing wastewater, concentrated waste water, which is an emulsion, enters the treatment facilities. As a result, the process of water purification is disrupted and it is not possible to achieve the required water quality in terms of "oil products".

To date, one of the most effective methods of wastewater treatment is a biological method. Biological treatment is the decomposition of the alien natural environment components implemented by nonchemical means. In the process of biological purification specific biological communities are used - active sludge, which includes bacteria, actinomycetes, microalgae, lower crustaceans [3], nematodes.

One of the ways to intensify the process of biodegradation of waste water components is the use of biologically active substances (BAS) as a stimulant of the process of biodegradation of pollution.

It is known that the activity of microorganisms of activated sludge stimulates the introduction of acids of the Krebs cycle into the wastewater. A method of biochemical treatment of wastewater from organic compounds in which sludge is pretreated with an aqueous solution of maleic or succinic acid, preferably in an amount of 0.01 to $1.00 \mathrm{mmol}$ per liter of sludge. As a result of such treatment, the degree of wastewater purification in terms of "chemical oxygen consumption» (COD) increased to $94 \%$ with a reduction in aeration time [4], [5].

It was found that the addition of aniline and hydrazine salts of bis (gidroksimetil) phosphine acid in concentrations of $10^{-7} \mathrm{~g} / \mathrm{dm}^{3}$ and $10^{-8} \mathrm{~g} / \mathrm{dm}^{3}$, respectively, have an inhibitory effect on the microorganisms of activated sludge [6].

To date, there is experimental evidence of the effectiveness of the substance "Etafos- $\mathrm{f}$ ", as an inhibitor or stimulator of growth in the number of destructors of water-miscible coolant brand "Incam-1" depending on the concentration of the substance [5].

\section{Methods}

In order to study the possibility of using this substance as an agent stimulating the process of purification of CFcontaining wastewater, two samples of CF-containing wastewater were selected at the engine plant of KAMAZ PTC, sent for treatment to the district treatment facilities.

Before the study, the main parameters of the samples were determined: appearance and smell - organoleptic, $\mathrm{pH}$ - on the ANION 4100 device, corrosion aggressiveness - by the imprint method [7], the total number of microorganisms [8]. The studies were carried out using activated sludge used at the district treatment facilities (DTF) in NaberezhnyeChelny. The index of activated sludge, determined before the study, was 60 , which corresponds to the requirements of microbiocenosis of treatment facilities [8].

For the biological treatment of the samples, the CF-containing wastewater components used in the following ratio: activated sludge $-30 \%$ of waste water $-70 \%$ (without Etafos-f); activated sludge $-30 \%$ waste water + Etafos-f in concentrations $10^{-4}, 10^{-5} \mathrm{~g} / \mathrm{dm}^{3}$.

The wastewater samples prepared for purification were aerated for 2 hours using the LAB-PU-02 device. PH, toxicity in dilutions were determined in the studied samples 1:10, 1:50, 1:100, the content of petroleum products [9]. 
Determination of toxicity by mortality of the test object was carried out according to the requirements of «The methodology for determining the toxicity of aqueous extracts from soil, sewage sludge and waste, drinking, wastewater and natural water mortality test object Daphnia magna Straus» [10].

\section{Results}

In the course of research it was determined that both samples are dirty-gray liquid with detached oil and a specific smell of hydrogen sulfide and petroleum products. The $\mathrm{pH}$ value of the first sample was 8.2; the second - 8.0. These values indicated the alkaline environment of the selected wastewater.

In the process of determining the corrosion aggressiveness of the selected effluents by the method of prints, a strong degree of corrosion aggressiveness of both samples with respect to metal surfaces was revealed (table.1).

\begin{tabular}{|c|c|c|c|}
\hline Sample No. & Point & The corrosion & The filter \\
\hline 1 & 4 & Severe corrosion & Solidcorrosion \\
\hline 2 & 4 & Severe corrosion & Continuous corrosion (one large spot with a diameter of $86 \div 86 \mathrm{~mm}$.) \\
\hline
\end{tabular}

Table 1: Corrosion Aggressiveness of Selected Samples of CF-Containing Wastewater

A strong degree of corrosion aggressiveness is the result of microbial damage to the $\mathrm{CF}$ during operation. Confirmation of the above reason is the high degree of contamination of the samples $\left(3 \times 10^{8}, 5 \times 10^{8}\right.$ cells $\left./ \mathrm{ml}\right)$ and a decrease in $\mathrm{pH}$ from 10.00 to $8.00-8.02$.

The results are presented in tables 2,3 .

\begin{tabular}{|c|c|c|c|c|c|c|}
\hline \multirow{2}{*}{$\begin{array}{l}\text { Concentration of } \\
\text { Etafos-f } \mathrm{g} / \mathrm{dm}^{3} \text {, } \\
\text { included in a } \\
\text { sample in } \\
\text { biological } \\
\text { treatment }\end{array}$} & \multirow[b]{2}{*}{ Dilution } & \multirow{2}{*}{$\begin{array}{l}\text { Time from } \\
\text { start of } \\
\text { biotesting }\end{array}$} & \multicolumn{2}{|c|}{$\begin{array}{c}\text { The number of surviving } \\
\text { Daphnia (in three parallel } \\
\text { definitions) }\end{array}$} & \multirow{2}{*}{$\begin{array}{l}\text { The mortality rate } \\
\text { of Daphnia in the } \\
\text { experiment, in \% of } \\
\text { control }\end{array}$} & \multirow{2}{*}{ Toxicity } \\
\hline & & & In control & $\begin{array}{l}\text { In experie- } \\
\text { nce }\end{array}$ & & \\
\hline \multirow{3}{*}{$10^{-4}$} & $1: 10$ & \multirow{6}{*}{ after 48 hours } & \multirow{6}{*}{30} & 6 & 80 & acute \\
\hline & $1: 50$ & & & 18 & 40 & chronic \\
\hline & $1: 100$ & & & 18 & 30 & chronic \\
\hline \multirow{3}{*}{$10^{-5}$} & $1: 10$ & & & 6 & 80 & acute \\
\hline & $1: 50$ & & & 6 & 80 & acute \\
\hline & $1: 100$ & & & 18 & 40 & chronic \\
\hline
\end{tabular}

Continuation of table 2 - The Impact of low concentrations of the drug, Etafos-f on the toxicity of runoff at the biological purification of CF-containing wastewater (sample No. 1)

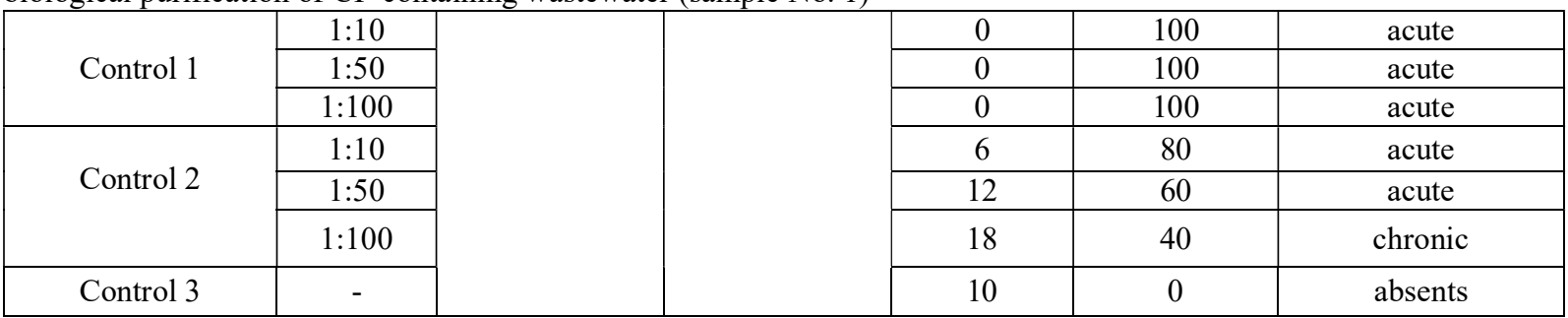

Table 2: The Impact of Low Concentrations of the Drug, Etafos-f on the Toxicity of Runoff at the Biological Purification of CF-Containing Wastewater (Sample No. 1)

\begin{tabular}{|c|c|c|c|c|c|c|}
\hline \multirow{2}{*}{$\begin{array}{l}\text { Concentration of } \\
\text { Etafos-f } \mathrm{g} / \mathrm{dm}^{3} \text {, } \\
\text { included in a } \\
\text { sample in } \\
\text { biological } \\
\text { treatment }\end{array}$} & \multirow{2}{*}{$\mathrm{pH}$} & \multirow{2}{*}{$\begin{array}{l}\text { Time from } \\
\text { start of } \\
\text { biotesting }\end{array}$} & \multicolumn{2}{|c|}{$\begin{array}{c}\text { The number of surviving } \\
\text { Daphnia (in three parallel } \\
\text { definitions) }\end{array}$} & \multirow{2}{*}{$\begin{array}{l}\text { The mortality } \\
\text { rate of } \\
\text { Daphnia in the } \\
\text { experiment, in } \\
\% \text { of control }\end{array}$} & \multirow{2}{*}{ Toxicity } \\
\hline & & & $\begin{array}{c}\text { In } \\
\text { control }\end{array}$ & In experience & & \\
\hline $10^{-4}$ & 7.31 & \multirow{5}{*}{ after 48 hours } & \multirow{5}{*}{30} & 30 & 0 & absents \\
\hline $10^{-5}$ & 7.50 & & & a litter30 & 0 & absents \\
\hline Control $1 *$ & 8.0 & & & 0 & 100 & acute \\
\hline Control 2** & 7.8 & & & 15 & 50 & chronic \\
\hline Control 3*** & 7.1 & & & 30 & 0 & absents \\
\hline
\end{tabular}

Table 3: Influence of Low Concentrations of the Drug, Etafos-f Toxicity CF-Containing Wastewater (Sample No.

2) After Biological Treatment

Note: * - untreated CF-containing wastewater; ** - CF-containing wastewater treated with activated sludge; *** cultivation water.

According to the data obtained during the experiment and reflected in table 2, untreated CF-containing wastewater exhibits acute toxicity. Daphnia mortality during the experiment was $100 \%$ within 48 hours. After biological treatment, 
adding a drug Etafos- $f$ in concentrations $10^{-4}, 10^{-5} \mathrm{~g} / \mathrm{dm}^{3}$ and in control 2 at a dilution of 1:100 were identified as chronic.

The data presented in table 3 indicate the presence of acute toxicity in untreated CF-containing wastewater. Mortality of Daphnia was $100 \%$ within 48 hours. Carried out after biological treatment with the addition of Etafos-f as an activator of activity of the biocenosis of activated sludge in solutions with concentrations of $10^{-4}, 10^{-6}, 10^{-7} \mathrm{~g} / \mathrm{dm}^{3}$ and in controls 2, 3 toxicity was absent. In the sample with a concentration of Etafos- $f 10^{-5} \mathrm{~g} / \mathrm{dm}^{3}$ revealed acute toxicity that may be indicative of incomplete purification of waste water.

The results of the toxicity study allow to determine the hazard class of these effluents for the environment. The studies were carried out in accordance with the criteria described in the Order of the MNRE RF № 536 dated 04.12.2014 "Criteria for classifying waste to I-V hazard classes according to the degree of negative impact on the environment" [11].

The definition of the hazard class of the sample No. 1.

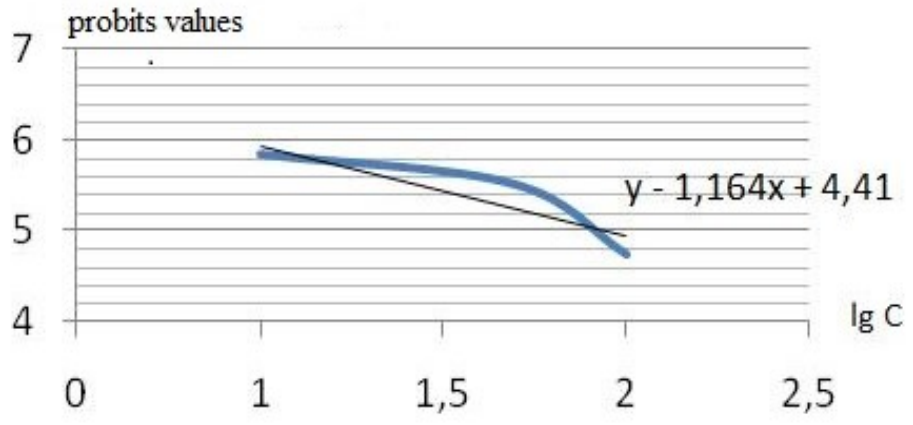

Fig. 1: The Death of Daphnia in the Sample No. 1

$$
\begin{aligned}
& L D R_{50-48}=100 / 10^{\wedge}((5-4,41) / 1,164)=31,13 \\
& H R D_{10-48}=100 / 10^{\wedge}((3,72-4,41) / 1,164)=391,55
\end{aligned}
$$

$\mathrm{LDR}_{50-48}$ - the average lethal multiplicity of dilution of the sample, causing the death of $50 \%$ of the test objects for 48 hour exposure.

$\mathrm{HRD}_{50-48}$ - harmless multiplicity of sample dilution, causing the death of no more than $10 \%$ of test objects for 48 -hour exposure.

According to the results of the bioassay conducted on the basis of their calculations, the CF-containing waste water can be attributed to the 3 class of hazard - moderately hazardous, as harmless dilution ratio equal 391.55 (which is in the range from 101 to 1000$)$.

The definition of the hazard class of the sample No. 2 .

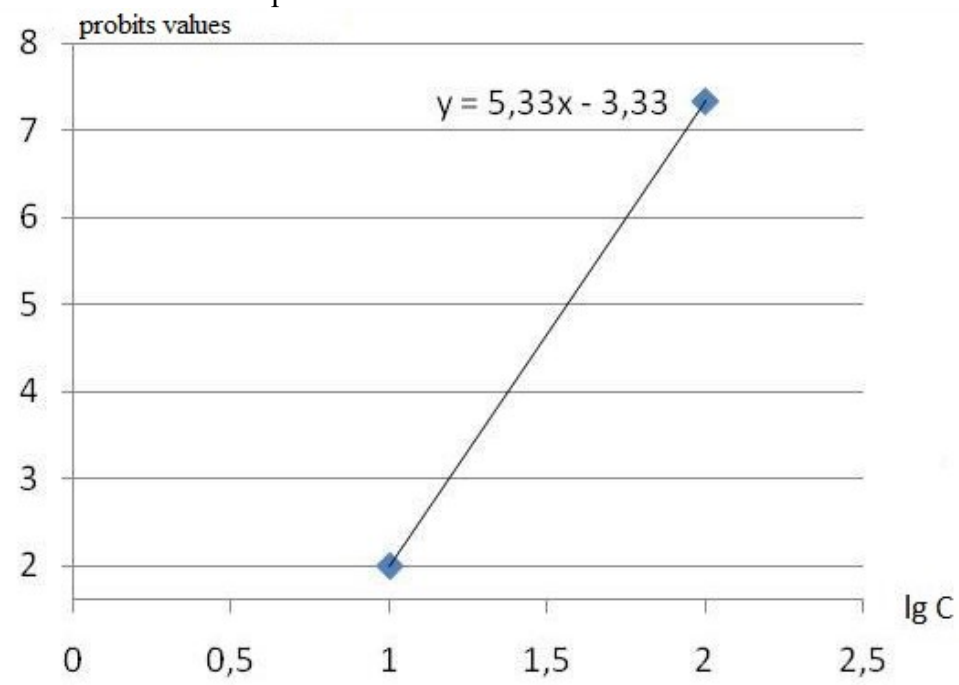

Fig. 2: The Death of Daphnia in the Sample No. 2

$$
\begin{array}{|l|}
\hline L D R_{50-48}=100 / 10^{\wedge}((5-3,33) / 5,33)=48,604 \\
H R D_{10-48}=100 / 10^{\wedge}((3,72-3,33) / 5,33)=84,494 \\
\hline
\end{array}
$$


$\mathrm{LDR}_{50-48}$ - the average lethal multiplicity of dilution of the sample, causing the death of $50 \%$ of the test objects for 48 hour exposure.

$\mathrm{HRD}_{50-48}$ - harmless multiplicity of sample dilution, causing the death of no more than $10 \%$ of test objects for 48 -hour exposure.

According to the results of biotesting and the calculations based on them, the CF- containing wastewater in sample No. 2 can be classified as hazard class 4 - low-hazard, since the harmless dilution ratio is 84.494 (which is in the range from 10 to 100$)$.

The results of the study the cleaning efficiency of the CF-containing sewage water with active silt and drug Etafos- $\mathrm{f}$ presented in tables 4,5 .

\begin{tabular}{|c|c|c|c|}
\hline Sample number & Concentration of Etafos-f, $\mathrm{g} / \mathrm{dm}^{3}$ & $\mathrm{pH}$ & Oil content, $\mathrm{mg} / \mathrm{dm}^{3}$ \\
\hline 1 & $10^{-4}$ & 7.3 & 21.75 \\
\hline 2 & $10^{-5}$ & 7.5 & 44.8 \\
\hline 3 & Control $1^{*}$ & 8.2 & 144.6 \\
\hline 4 & Control $2^{* *}$ & 7.8 & 63.99 \\
\hline
\end{tabular}

Table 4: Influence of Low Concentrations of the Drug, Etafos-f on the Oil Content in the Biological Treatment of the CF-Containing Wastewater (Sample No. 1 (Without Dilution))

Note: * - untreated CF-containing wastewater without dilution; ** - treatment of CF-containing wastewater with active sludge.

The data presented in table 4 show that the content of petroleum products is most effectively reduced $\left(21.7 \mathrm{mg} / \mathrm{dm}^{3}\right)$ in the treatment of CF-containing wastewater with the addition of Etafos-f with a concentration of $10^{-4} \mathrm{~g} / \mathrm{dm}^{3}$. the Addition of the above substance in this concentration allowed to reduce the content of petroleum products by 7 times compared to the initial sample $\left(144.6 \mathrm{mg} / \mathrm{dm}^{3}\right)$ and 3 times compared to the classical biological treatment of crude CFcontaining $\left(63.9 \mathrm{mg} / \mathrm{dm}^{3}\right)$ wastewater.

\begin{tabular}{|c|c|c|}
\hline $\begin{array}{c}\text { Sample } \\
\text { Number }\end{array}$ & $\begin{array}{c}\text { Concentration of Etafos- } \mathrm{f}\left(\mathrm{g} / \mathrm{dm}^{3}\right) \text {, added to the sample in biological } \\
\text { treatment }\end{array}$ & Oilcontent, $\mathrm{mg} / \mathrm{dm}^{3}$ \\
\hline 1 & $10^{-4}$ & 14 \\
\hline 2 & $10^{-5}$ & 24.84 \\
\hline 3 & Control 1: initial CF-containing waste water $(\mathrm{pH}=8.0)$ & 78.72 \\
\hline 4. & Control 2: CF-containing waste water with activated sludge & 24.38 \\
\hline
\end{tabular}

Table 5: The Impact of Low Concentrations of the Drug, Etafos-f on the Oil Content in the Biological Treatment of the CF-Containing Waste Water (Sample No. 2 (Without Dilution))

According to table 5, the content of petroleum products is most effectively reduced $\left(14.0 \mathrm{mg} / \mathrm{dm}^{3}\right)$ in the treatment of CF-containing wastewater with the addition of Etafos- $f$ in a concentration of $10^{-4} \mathrm{~g} / \mathrm{dm}^{3}$. The addition of the substance in this concentration allowed to reduce the content of petroleum products 6 times compared to the initial sample (78.7 $\left.\mathrm{mg} / \mathrm{dm}^{3}\right)$ and 2 times compared to the classical biological treatment $\left(24.3 \mathrm{mg} / \mathrm{dm}^{3}\right)$. In the samples with other concentrations of Etafos- $f$ the oil content varied from 18.3 to $28.6 \mathrm{mg} / \mathrm{dm}^{3}$.

\section{Discussion}

Analysis of the data in tables 4, 5 and figure 3 leads to the conclusion that the use of the substance "Etafos- $\mathrm{f}$ " in the concentration of $10^{-4} \mathrm{~g} / \mathrm{dm}^{3}$ in the biological treatment of CF-containing wastewater as a stimulator of activated sludge biocenosis, as well as to minimize the death of aerobic microorganisms involved in the biological treatment of industrial waste.

\section{Conclusions}

The results indicate the possibility of using the substance "Etafos-f » as an activator of activity of the biocenosis of activated sludge in the purification of CF-containing waste water from oil products.

\section{Acknowledgements}

The work is performed according to the Russian Government Program of Competitive Growth of Kazan Federal University. 


\section{References}

1. Smirnova N.N., Dinmukhametova A.I. Toxicity of water-soluble lubricant cooling liquids / N.N. Smirnova//Interuniversity scientific collection Design and research of technical systems. - NCh: Publishing and printing center of Kama state Academy of engineering and Economics, 2009. - №13. - P.139-141.

2. Smirnova N. N., Sharafutdinov R.N., Akhmetov V.M. Microbic destruction of emulsion lubricant cooling liquids and methods of her prevention / N.N. Smirnova//Total scientific conference of the faculty. Collection of reports. NCh: LF.: Printing center of Naberezhnchelninsky institute of K(P)FU, 2013. - P.234-238.

3. Konovalov I. A. Education of nanodimensional molecular ensembles in extremely diluted water solutions / I.A. Konovalov// The magazine of the Russian Academy of Sciences. - M: Science, 2013. - T. 83. - № 12. - P. 10761082.

4. Lesnova E.A. Influence of a melafen on representatives of active Daphnia Magna Straus silt and microalga / E.A. Lesnova, N.N. Smirnova, S.V. Friedland //Messenger of the technological university. - K.: Federal state budgetary educational institution of higher professional education "Kazan national research technological University», 2014. - T.17, № 10. - P. 137-139.

5. Smirnova N.N. Influence of the medicine Etafosf on microbiological and anticorrosive properties // Topical issues of the science, technology and production cooling WSL to lubricant Monks-1 / N.N. Smirnova, G.V. Mavrin, T.R. Denisova, S.V. Friedland: materials III International scientific and practical conference on November 21-22, 2014, St. Petersburg / International union of scientists "Science. Technologies. Production". - St.P.: International union of scientists "Science. Technologies. Production", 2014. - P. 46-49.

6. Roshchina, O.S. Influence of chemical factors on the biocenosis of activated sludge in the process of biological treatment of wastewater from organic production / OS Roshchina, TP Pavlova, SV Friedland // Bulletin of Kazan Technological University. - K.: Federal state budgetary educational institution of higher professional education "Kazan national research technological University», 2012. - T.15. - №10. - P.190-194.

7. GOST 6243-75. Emulsola and paste. Test methods. - Vved. 1976-07-01. - M.: Publishing house of standards, 1975. $-9 \mathrm{p}$.

8. GOST 9.085-78. Unified system of corrosion and aging protection. Liquids lubricant cooling. Test methods on bioproofness. Vved. 1979.07.01. - M.: Publishing house of standards, 1979. - $32 \mathrm{p}$.

9. SG 4.1.1262-03. Control methods. Chemical factors measurement of mass concentration of oil products by a fluorimetrichesky method in tests of drinking water and water of superficial and underground sources of water use. - Vved. 2003-09-01. - M.: Russian Ministry of Health, 2003. - 28 p.

10. NPNDF 16.1:2.3.3.9-06. A technique of determination of toxicity of water extracts from soils, rainfall of sewage and waste, drinking, waste and natural water on mortality of a test object of Daphnia Magna Straus. - Vved. 2006. - M.: State committee of the Russian Federation on environmental protection. $-13 \mathrm{p}$.

11. Order MNRaE from 04.12.2014 N 536 "Criteria for categorizing waste to I-V hazard classes according to the degree of negative impact on the environment" // System GARANT. - Access mode: http://base.garant.ru/71296500. - Date of application: 01.06.2018. 